\title{
The Role of Small Towns for Surrounding Rural Development: The Case of Metema Town, North West Ethiopia
}

\author{
Kassahun Gashu \\ Department of Geography and Environmental Studies, University of Gondar, Gondar, Ethiopia \\ Email: kg19me@gmail.com
}

Received 3 July 2014; revised 13 August 2014; accepted 19 September 2014

Copyright (C) 2014 by author and OALib.

This work is licensed under the Creative Commons Attribution International License (CC BY). http://creativecommons.org/licenses/by/4.0/

(c) (i) Open Access

\begin{abstract}
There is a growing need to identify the most appropriate mechanisms through which to stimulate economic activity across a broad range of economic sectors in rural areas. One strategy is to use small towns as "sub-poles" in rural economic development but the effectiveness of such a strategy depends not only on the size of the various multipliers but their spatial distribution. The spatial economic data from small town that were used to measure the strength of economic integration between town and hinterland help to estimate the magnitude of town-hinterland spill-over effects. The potential value of a town as a "sub-pole" in local economic development is shown to be dependent on structural differences in the local economy, such as the particular mix of firms within towns. The policy context and theoretical underpinnings of some recent and on-going studies are examining the potential role of small towns in rural development. An operational framework is described which aims to examine the sectoral and locational variations which may affect the success of any small town sub-pole strategy, using some developed empirical tools to measure economic linkages. It then goes on assessing the potential role of small towns as sub-poles for rural development. The paper concludes with some suggestions for future research in this field.
\end{abstract}

\section{Keywords}

Small Towns, Rural Development, Sub Pole, Regional Development, Metema

Subject Areas: Economics, Human Geography

\section{Introduction}

Small towns are increasingly being perceived as a possible focus for initiatives that seek to maintain or enhance the rural economy. The ability of small towns to generate economic growth in rural areas depends on the nature 
and strength of the linkages between the town and its surrounding hinterland (and vice versa). These are determined by the extent to which: Hinterland households earn income in the towns; Town households spend income in the hinterlands; and Town businesses source inputs (labour and goods and services) in the hinterlands.

These linkages work in both directions. Small towns and their surrounding rural areas are a part of the same functional economic system and, as a result, numerous different types of economic linkages exist between them. A farmer may rely on neighboring towns for agricultural inputs, shopping, schools, healthcare and farm labour. A resident in a small town may use the rural hinterland for recreation and as a source of local food while a town employee may choose to live in the surrounding rural area and commute to work.

As a result of these links, small towns form an important component of rural economy and society. Increasingly, they are being perceived as a possible focus for initiatives that seek to maintain or enhance the well being of rural areas as a whole.

From a rural development perspective, the spatial distribution of linkages between a small town and its hinterland is just as important as their size. Some authors such as Tacoli C. [1] have shown that the economic footprint of different types of firms and different types of households vary. For instance, small firms tend to be more locally integrated than larger firms; retirees tend to spend a higher proportion of their income locally than single adults with no dependants. At another level, the relationship between small towns within a region can influence development trajectories. Urban-rural relations emphasize the potential for reducing inequalities between areas by pursuing polycentric objectives. In other words by developing complementary roles for adjacent small towns, overall rural development can be enhanced. This is likely to be particularly important in more remote rural areas [1].

Spatially, tracking the nature of linkages between town and countryside and considering the nature of economic relations between small towns considerably add some new ideals to the current understanding of spatial development in rural areas.

\section{Statement of the Problem}

Small towns are potentially attractive as a focus for future rural development initiatives for a number of reasons. In the first place, they may provide the opportunity to foster beneficial economic development while conserving the environmental assets of the open countryside, confining new built development to existing urban settlements and reducing the need for the town's residents to commute to work elsewhere. Second, they may already contain the concentrations of community and institutional capacity necessary to manage local, regional or national initiatives in a reliable and accountable manner. Finally, the concentration of rural economic development initiatives in small towns may take advantage of economic advantages of population clusters while allowing the benefits (in terms of both employment and income) to spread out to the surrounding countryside.

In the Ethiopian context, questions that need responses are many. Plan for Accelerated Sustainable Development to End Poverty (PASDEP), in its fourth pillar which promotes small town development motivates rural-urban linkage [2] [3]. However, there are no sufficient studies on small towns as sub-poles for rural development. Such study will provide a general perspective on the role of small towns in attaining over all development. Hence, this study attempts to fill this gap focusing on small towns' role on surrounding rural areas development. Several lessons can be drawn from this study, such as, factors that affect rural-urban interaction between small towns and their rural hinterlands; the current forms and magnitudes of rural-urban interaction, and the services and facilities provided by small towns. The Answers to these questions and others will help to enhance rural-urban interactions and the role played by small towns for sustainable and mutual development of urban and rural areas.

\section{Objectives of the Research}

\subsection{General Objective}

The General objective of this research is to analyze the role of small towns for the development surrounding rural areas.

\subsection{Specific Objectives}

The specific objectives of this research are to: 
- Examines the different types of economic linkages that exist between Metema town and its surrounding rural areas.

- Measure the strength of economic integration between Metema town and its hinterland.

- Evaluates the potential value of Metema town as a "sub-pole" in local economic development.

- Identify of the social, cultural, and multiplier effects of investing in small towns and hinterlands.

- Discuss the policy implications of the results.

\section{Research Questions}

In rural-urban interactions study, a range of physical, economic and service linkages have to be examined. As Rondenilli and Evans (1983) stated cited by Demeke [4], some of these are transport links, production and marketing links, the delivery of social services (health, education), technological linkages related with energy and communication, and public administration linkages.

Based on these concepts and the objectives forwarded above for the study, the following research questions are formulated.

- What are the factors that affect rural-urban interaction between small towns and surrounding rural areas?

- What are the major non-farm activities undertaken by farm households in the hinterlands of small towns? And what roles do they play in promoting rural-urban linkage?

- To what extent do rural households use agricultural inputs? From where do they obtain these inputs?

- To what extent do small towns depend on their rural hinterlands for agricultural produce consumption, labor and trading activities?

\section{Research Methodology}

\subsection{Data Sources and Sample Size}

\subsubsection{Data Sources}

In order to conduct this research and to identify the different types of linkages data will be collected from both primary and secondary sources. In the collection of primary data, questionnaire and personal observations will be conducted in sample rural and urban areas and interviews will also be conducted with responsible personnel's of corresponding woreda agricultural and rural development offices of Metema woreda and municipality of Metema town.

Three sets of questionnaire pertaining to rural households, urban households and traders will be prepared. The questions included in the questionnaire are related to linkages of consumption, production, and service provision in addition to socio economic characteristics such as demography, land holding and others that helps for the explanation of the phenomena.

The secondary data were derived from relevant organizations such as CSA, Woreda agricultural office, Amhara Region Bureau of Agriculture (ARBoA), Zonal planning offices, Municipality of the sample Metema town and others.

\subsubsection{Sample Plan and Size}

A two stage sampling design was used in the data collection. For the rural households, two rural kebeles with in a $10 \mathrm{~km}$ radius from the town were selected randomly in the first stage. The roasters of peasant associations were used as sampling frame. Similarly from two kebeles of Metema town two kebeles of the town were selected purposively. The urban kebele administration was used as a sampling frame. Formulas often used in most social science researches for sample size determination when the target population is less than 10,000. According to some authors like, Yamane [5] provides a simplified formula to calculate sample sizes.

$$
n=\frac{N}{1+N(e)^{2}}
$$

where: $n$-is the sample size; $N$-is the population size and $e$-is the level of precision (confidence).

Substituting the value of $N$ in the above formula the actual sample household number are calculated for both urban (where $N=11,118$ ) and rural (where $N=69,428$ ). The method results a sample size of 347 and 56 urban and rural households respectively. However, out of 56 urban sample households, 40 valid samples (30 urban 
households and 10 traders) were entered in to the analysis. Likewise, out of 347 rural sample households, 315 valid samples were entered in to the analysis. The remaining samples (16 urban sample households and 32 rural sample households) are accounted to be unacceptable because enumerators missed pertinent variables at the time of data collection and it was not viable to make an interview for the second time due to time and money constraints.

Besides, the researcher believes that such insignificant number will not have any major effect on the results of the study. Number of sample households in each kebele was determined as per of the proportion to the population size and samples are drawn using systematic sampling method.

\subsection{Method of Data Analysis}

In the analysis of the data, both quantitative and qualitative methods will be used to examine the existing rural-urban linkage and its implications in the role of small towns in rural development. Quantitatively simple statistical tools such as percentages, means, standard deviation, charts, chi-square and ANOVA were used. The qualitative part includes analysis of attitudes, opinions, and suggestion of informants.

\section{Factors Affecting Rural-Urban Interaction for Development}

The factors that affect linkages between rural and urban areas are various. Among other things, some of them are Agriculture research and Development, Information and communication technologies, Infrastructure development and market institutions [6]-[15].

Science and technology are fundamental for rural-urban linkages and in this context Agriculture Research is fundamental. The Green Revolution experience which include high-yielding varieties complemented with irrigation and intensive fertilizer use especially in Asia has shown that research and development can result in technological breakthrough that enable considerable improvement in agricultural growth, which in turn can translate into substantial rural development and poverty reduction [15].

Information and communication technologies can lower transaction cost by reducing information bottlenecks that hinder rural-urban linkage and by increasing search, screening and bargaining costs and Information Communication Technologies opening-up market possibilities for rural inhabitants [13] [15].

Infrastructure works as a bridge between the rural and urban world, and between agricultural sector and other sectors of the economy. In addition to direct impact, infrastructure may indirectly affect rural and urban linkages [10] [13] [15].

In developing countries, particularly low income ones, market failures such as deficiencies in information and lack of regulation and legal enforcement mechanisms persist and restrict the level of trade between urban and rural areas. Local rural-urban linkages can vary according to the larger spatial networks of towns, cities, and transformation and communication flows [7] [15].

Rural-Urban interaction is affected by economic situation and budget cutbacks. One of the marked distinctions between rural and urban areas in developing countries is consumption expenditure [14]. Strengthening rural-urban interaction without a capacity of rural areas to capture the upstream (providing inputs) and downstream (processing and marketing) activities associated with natural resource extraction and flows will only perpetuate low incomes [14] [16].

There are regional differences in rural-urban interaction. In Nigeria the linkages are stronger in the southwest and the eastern region than in the northern region [14]. Differentials in physical development can be partly traced to this unequal rural-urban linkage between parts of the north and the south. Regions that had stronger rural-urban interaction have lower poverty level as compared to the areas, which had weaker linkages.

Moreover, socio-economic relations, structure of the rural economy, natural environment, and resources, rural production regimes process and pattern of urbanization, lack of balance rural-urban policy, land tenure and size are also factors determining rural-urban linkage [4] [7] [9]-[12].

\section{Background of the Study Area}

\subsection{Location}

Metema woreda is one of the woredas in North Gondar administrative zone of Amhara National Regional State. It is the largest woreda in the zone. The woreda is divided in to twenty two administrative kebeles. Two of the 
kebeles are found in the woreda capital, while the rest are rural kebeles. The woreda is bounded by Tacharmachiho woreda in the North, Chilga woreda in the East, Quara woreda in the South and Sudan in the West (see map below). This study was conducted in Metema woreda of the Amhara National Regional State (ANRS). Metema is located at about $900 \mathrm{~km}$ Northwest of Addis Ababa and about $180 \mathrm{~km}$ West of Gondar town. Metema is one of the Western Woredas of the Amhara Regional State. The woreda has an international boundary of more than $60 \mathrm{~km}$ with Sudan (Figure 1).

\subsection{Topography and Areal Coverage}

The topography of Metema Woreda is characterized by plain land. This indicates that larger proportion of the woreda is characterized by more than 90 percent less than $1000 \mathrm{~m}$ above sea level. The elevation of the woreda ranges from 500 meters to 1666 meters above sea level. The total areal coverage of the woreda is about 440,085 hectars.

\subsection{Climate}

According to Woreda Agricultural and Rural Development Office, the woreda has kola agro-ecological zone with annual temperature range 28 - 43 degree centigrade. The daily maximum temperature becomes very high during the months of March to May, during which the temperature can reach as high as $43^{\circ} \mathrm{C}$. The mean annual temperature is about $31^{\circ} \mathrm{C}$ [17]. Mean annual rainfall of Metema area ranges from about 850 to around $1100 \mathrm{~mm}$, and it receives a uni-modal rainfall [17]. The rainy months extend from June to the end of September. However, most of the rainfall is received during the months of July and August, during which the rainfall is erratic.

\subsection{Land Use}

According to the Woreda Agriculture and Rural Development Office, the land use of the woreda is classified in

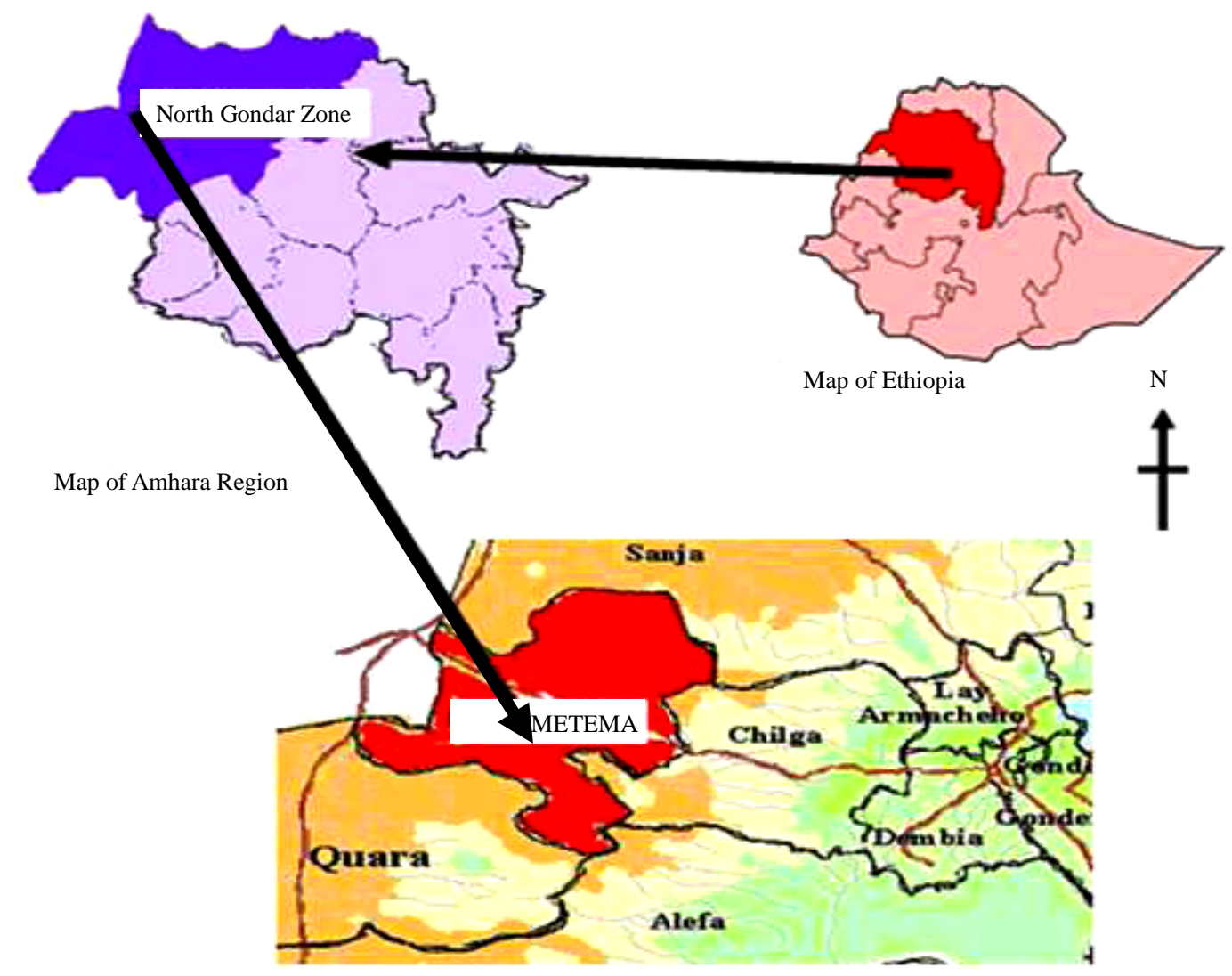

Figure 1. Map of the study area. 
to 86,360 hectare for farmland; 4400 hectare for grazing; 177,600 hectar for forest; 3,660 hectare for settlement from this 894 hectare is used for social services; 116.2 hectare for perennial crops; 89,943 hectare for bushes and shrubs; 3708 hectare water bodies; 17,471 hectare could be cultivated; 7752.2 hectare unusable and the remaining 6800 hectare is for miscellaneous activities. Forest and bush land are diminishing over time due to farm land expansion.

This depicts that, the land use type and pattern of Metema woreda is more diversified. The nature of land use in the woredas is that larger proportion of the land is used for forest land. The land area used for perennial crops (about 0.03 percent) is smaller than others followed by irrigable land and settlement area and land covered by water bodies respectively.

\subsection{Population}

According to CSA [18] [19], the population of Metema Woreda was about 110,231. Of the total population 88,354 (80.15 percent) are rural inhabitants and 41,229 (46.66 percent) are female. This indicates that the numbers of rural inhabitants are more numerous than urban dwellers and the number of male and female population in the woreda are proportional. The inhabitants of the woreda are belonging to the Amahra ethnicity and Amharic and to some extent Arabic are media of communication. With regard to religion almost all inhabitants are followers of Orthodox Christians (90 percent), but there are few Muslims residing in the urban kebeles of the woreda. The population density of the woreda is about 25 persons per square kilometers.

The original residents of the area were Gumuz. Until recently, they have practiced slash and burning and hunting wild animals. They have also been engaged in making household furniture like chair, bed, pot and others. When the area became gradually populated, the natives were dominated by the new settlers. The original settlers (Gumuz) are now found only in three peasant associations, the Kumer Aftit, Tumet and Shinfa.

The total number of the indigenous people is around 500 [ILRI, 17]. Hence, much of the area is recently occupied by settlers from the highland part of the region. According to WoARD [20], in the years of 2003, 2004 and 2005 during which new settlement programs occurred, 12,777, 4124 and 16,258 new settlers were settled in the district, respectively. It shows that the population of the woreda capital, Metema and the Woreda as a whole increases rapidly from year to year.

\subsection{Farming System}

The major economic activity in the woreda in which the population engaged is mixed farming, which is a combination of crop production and livestock rearing and to some extent legal and illegal trade because of its proximity to the border. Due to erratic and torrential rainfall pattern farming operation is always at risk such as crop failure due to drought, shortage of livestock feed etc.

The agricultural production system in the study area is crop-livestock mixed. The crop-livestock mixed production system is the predominant system and exists in all over the district throughout the year. Crop production is the main agricultural activity for the livelihood of the smallholder farmer in the study area. The major crops grown include sorghum, rice, cotton, sesame, haricot bean, soybean and new emerging crops like teff, chickpeas and banana.

Livestock production is an integral part of the land use system. Production of cattle (as draught power, milk and meat), shoat (income and meat), donkey and camel (as Karoo and transport) and poultry was commonly practiced. WoARD [20] report shows that the livestock population of the district is composed of 136,910 cattle, 32,024 goats, 1686 sheep, 7164 male donkeys, 7127 poultry, 400 camels and 23,789 beehives. Cattle in the district are exported both legally and illegally, through smuggling to Sudan, while goats and other animals are mainly sold in local markets.

According to ILRI [17], Metema district was categorized into cotton, sorghum and rice/ livestock based/ and sesame, cotton, and sorghum/ livestock based farming systems based on the type of crop production. The livestock production system is similar in both farming systems. Therefore, there are two types of farming systems used in the study district namely cotton based farming system and sesame based farming systems. Each has its own characteristic features regarding to the crop production nature.

According to ILRI [17] 4 out of 18 peasant associations (PAs) belong to cotton farming system. They are Maka, Awlala, Genda Wuha and Kemechela. They are found in the Northeast parts of the district. The PAs are relatively colder in temperature, have higher altitude and rainfall. Farmers in the PAs practice slightly early 
planting of crops. The soil is black and water logging is a problem. The majority of the soils in this farming system have vertisoil property.

Many of the areas are also flat. The PAs in this farming system have different features in terms of suitability for crop production and amount of rainfall received. The majority of the soils are only suitable for growing cotton and rice. The PAs predominantly grow cotton and sesame in little amount. Cotton is grown in wide areas while sorghum and sesame are planted on very smaller areas.

Fourteen PAs belong to sesame based farming system. In order of importance, sesame, cotton and sorghum are the major crops produced in this farming system. A farmer could grow any one of these crops as the environmental conditions are equally suitable for these crops. The choice is set by the farmer upon observation of the season, high or low rainfall, and possible market prices. The altitude and rainfall in this farming system is less than the cotton based farming system. The altitude range for this farming system is between $550 \mathrm{M}$ and $700 \mathrm{M}$ above sea level [17].

Farmers and agriculturists believe that the underground water table is high. In some places, sufficient amount of water could be obtained at less than 10 meter deep. Besides, three rivers are found in this farming system. These rivers make the area more potential for crop and livestock development. This farming system also has extensive grazing areas. There is also a place where the natural plantations for gum and incense are located.

\subsection{Infrastructure}

The availability of sufficient economic, social and physical infrastructure directly influences rural-urban linkages and the potential that small towns could play in balanced development process. Physical and social infrastructures with no doubt play a key role for rural and regional development.

A research on the rise of secondary cities also identifies ground transportation (roads and railways) as essential infrastructural investments. Road access within and between small towns and their hinterlands could faster rural-urban linkages in the form of production and consumption linkages. Social infrastructures like schools, health services, telecommunication, postal and banking services are also seen as necessary investments for development. The next section gives a general overview on physical and social infrastructure developments in the study areas.

\subsubsection{Physical Infrastructure}

The nature of land scope, resource endowment, policy environments of the government are among other things, some of the factors that resulted in unbalanced development of physical and social infrastructure.

1) Road Transport: The main asphalt road from Addis Ababa to Metema via Gondar about $800 \mathrm{~km}$ far from Addis Ababa could reach Metema woreda. The total length of the available road is about $483 \mathrm{~km}$. It has $80 \mathrm{~km}$ asphalt road that is part of the main high way to Sudan, $55 \mathrm{~km}$ Gravel road and $348 \mathrm{~km}$ dry weather road joining kebeles each other in the woreda.

2) Water and Electricity: Efficient and effective production and consumption linkages could be promoted by the development and availability of such urban infrastructures like water and electric power supply.

Most of woreda capitals and even other minor towns in North Gondar zone receive electric power and are connected to the national grid. Surprisingly, the same is not true for Metema town. This town enjoys electric power supply during most of the days for about a maximum of 4 hours using private generators. However, in Metema woreda one rural kebele (Kokit), and three urban kebeles (two kebeles of Gendewuha, woreda capital and one kebele of Shenfa) have an access to 24 hours electric power.

With regard to water service at the woreda level, the woreda has about 19 rural kebeles with shallow wells and about 2 rural kebeles with hand pump wells. This indicates that about 86.36 percent of the rural kebels in the woreda are users of water supply. At the woreda level, it covers about 75.83 percent of the woreda's population.

\subsubsection{Social Infrastructure}

Similar to physical infrastructure social and institutional infrastructures such as education and health facilities, bank and/or credit services, and postal and telecommunication services are also important in promoting ruralurban linkages between hinterlands and towns for enhancing a more productive economy.

1) Education and Health Services: The comparison of distribution of social infrastructures such as education and health services at the woreda level, more or less there are proportional number of educational and health 
centers. The only difference is that there are one high school and preparatory school one vocational training which is administered by woreda education office.

2) Telecommunication and Banking Services: At the woreda level the study area Metema town in Metema woreda has no digital telephone service and there about no clients for fixed telephone. Recently from the rural kebeles found in the woreda almost all kebels are users of wireless telephone service. However, the service is intermittent and has no quality.

Moreover, Metema town has no postal service. As far as the banking service is concerned, at the woreda level, there are three banks in Metema town, two of them private and one government bank, commercial bank of Ethiopia.

\subsection{Investment}

Currently, there are investors who are engaging in agricultural sector in the woreda. These investors owned about 28,816 hectare of land. Of these majorly 94 are found in Delelo, 84 in Tumet and 386 minor investors in different parts of the woreda. These investors create employment opportunity for the local people and people from different corners of the country. They employed 4420 permanent employees and about 38,100 daily workers. All of them account about more than 129 million Birr fixed capital and more than 86 million Birr recurrent capital.

\section{Patterns of Rural-Urban Linkage}

\subsection{Frequency of Visit to Small Towns}

Production, consumption and public service linkages are some of the basic forms of rural-urban linkages that may occur between urban centers and their surrounding hinterlands. The frequency of visit of farm households to the nearby towns helps to detect the observed patterns of linkage. Towns are expected to provide markets for agricultural produce, serve as source of urban goods and services and off-farm employment to their hinterland people.

Since they are found at the lower level of urban hierarchy and are immediate destinations of rural people who live in the hinterlands, small towns are the most frequently visited centers by the rural people. In the same way, small towns in the study areas are the most frequently visited centers by almost all the sample households. The pattern of the frequency of visit varies from daily to once a month. As a result the observed frequencies of visit from different hinterlands are not the same (see Table 1).

Majority of the sample rural households in both kebeles visit the nearby small twice a week followed by once in a week and once a month. A chi square and ANOVA revealed that there is a significant difference in the frequency of visit between the two sample populations (see Table 2).

Table 1. Frequency of Visit to the nearby small towns by PAs (number and percentage of households).

\begin{tabular}{|c|c|c|c|c|c|c|}
\hline \multirow{3}{*}{ Frequency } & \multicolumn{6}{|c|}{ Metema Woreda } \\
\hline & \multicolumn{2}{|c|}{ Kumeraftit } & \multicolumn{2}{|c|}{ Kokit } & \multicolumn{2}{|c|}{ Total } \\
\hline & No & $\%$ & No & $\%$ & No & $\%$ \\
\hline Daily & 11 & 15.71 & 15 & 12.5 & 26 & 13.68 \\
\hline Once a week & 10 & 14.28 & 37 & 30.83 & 47 & 24.74 \\
\hline Twice a week & 37 & 52.86 & 43 & 35.83 & 80 & 42.1 \\
\hline Four times a week & 1 & 1.43 & 3 & 2.5 & 4 & 2.1 \\
\hline Once a month & 1 & 1.43 & 1 & 0.83 & 2 & 1.1 \\
\hline Twice a month & - & - & 2 & 1.67 & 2 & 1.1 \\
\hline Total & 60 & 85.71 & 101 & 84.73 & 161 & 84.73 \\
\hline
\end{tabular}

Source: Own Survey (2011) Note: No—Number, \%—percentage. 
Table 2. Chi square and R-value for frequency of visit by kebele.

\begin{tabular}{|c|c|c|c|c|c|c|c|}
\hline Woreda & 1 & 2 & 3 & 4 & 5 & 6 & Sum \\
\hline Kumeraftit kebele & $15(19.53)$ & 107(85.95) & $55(75.35)$ & $2(3.35)$ & $25(15.07)$ & 22(13.39) & 240 \\
\hline Kokit kebele & $20(15.46)$ & 47(68.05) & 80(59.65) & $4(2.65)$ & $2(2.65)$ & $2(10.6)$ & 190 \\
\hline Sum & 35 & 154 & 135 & 6 & 27 & 24 & 430 \\
\hline \multicolumn{8}{|c|}{$\begin{array}{l}\text { D.F }(\text { two tailed })=5 . \\
\text { Table value }(\text { two tailed })=11.07 \text {. } \\
\text { Level of significance }(p)=0.05 \text {. }\end{array}$} \\
\hline
\end{tabular}

Standardized Residual (R-value) for frequency of visit

\begin{tabular}{ccccccc}
\hline Woreda & 1 & 2 & 3 & 4 & 5 & 6 \\
\hline Kumeraftit kebele & -1.03 & 2.27 & -2.11 & -0.74 & 2.56 & 2.35 \\
Kokit kebele & 1.15 & -2.55 & 2.63 & 0.83 & -2.87 & -2.64 \\
\hline \multicolumn{7}{c}{$R=\frac{(O-E)}{\sqrt{E}}$}
\end{tabular}

A variety of reasons are presented by sample households for visiting nearby small towns in the study areas. Among other things, market attendance to buy and sell items takes the largest share. Except this, all other purposes differ between the study sites in both kebeles, though there are multiple purposes (responses). In kumeraftit kebele, farm households in the study sites reported that others (asking relatives, recreations, meeting etc), administration (court, police etc), social service (education, health) and lastly daily labour as their second to fifth reasons to visit nearby small town.

However, in kokit kebele sample farm households presented daily labour as their second most important reason followed by administration for visiting nearby small town (see Table 3). This falls in line with the expectation that farmers in food insecure area rely on the town for their livelihood.

Regarding the mode of transportation to the small towns, sample farm households in the study sites reported that about 65 percent in kumeraftit kebeke and about 95 percent in kokit kebele visit small town on foot. However, about 33 percent in kumeraftit kebele use either pack animals like cart, public transport or other means such as bicycle, while about 5 percents in kokit kebele use pack animals only (see Table 4).

Measuring in all these indicators and under the characteristics of farm economy like land holding size, livestock production and the volume of crop production between sample farm households in Metema woreda of North Gondar zone, the sample farm households in kumeraftit kebele are in a better position than their counter parts. The need to supplement low agricultural production in kokit kebele, on the other hand lead to participate in low return non-farm activities. Therefore, we can generalize that the patterns of visit of small towns by hinterland people differ depending on the level of production of households.

\subsection{Factors Affecting Rural-Urban Linkage in the Study Areas}

As it is stated in the literature factors that affect rural-urban linkage can be categorized broadly as global, national and local factors. Largely it is the local factors that affect the linkage of small towns and their surrounding hinterlands. Several local factors are postulated to determine rural-urban linkages in the study areas.

These local factors can affect frequency of visit to the nearby small towns, pattern of input usage, the utilization of public service facilities, the consumption pattern of basic consumer and consumer durable goods, the participation in non-farm activities are supposed to have a significant influence. Some of these factors are income from agricultural activities and production status and resource endowment; distance from small towns; infrastructure development; non-availability of financial institutions and service provision capacity of towns.

It is very difficult to see these factors separately. Because one factor directly or indirectly influences the other and largely may lead to vicious circle. 
Table 3. Reasons (purposes) for visiting small towns by PAs (number and percentage of households).

\begin{tabular}{cccccccc}
\hline & \multicolumn{5}{c}{ Metema woreda } \\
\cline { 2 - 7 } Reason/Purpose & \multicolumn{2}{c}{ Kumeraftit kebele } & \multicolumn{2}{c}{ Kokit kebele } & \multicolumn{2}{c}{ Total } \\
\cline { 2 - 7 } & No & $\%$ & No & $\%$ & No & $\%$ \\
\hline Buy and sell items & 67 & 74.44 & 98 & 65.33 & 165 & 68.75 \\
Social service & 4 & 4.44 & 15 & 10.0 & 19 & 7.92 \\
Administration & 23 & 25.26 & 13 & 8.67 & 36 & 15.0 \\
Daily labor & 2 & 2.22 & 5 & 3.33 & 7 & 2.92 \\
Other & 21 & 23.33 & 26 & 17.33 & 47 & 19.58 \\
\hline
\end{tabular}

Source: Own survey (2011).

Table 4. Mode of transport to visit small towns by kebele.

\begin{tabular}{|c|c|c|c|c|}
\hline \multirow{2}{*}{ Mode of transport } & \multicolumn{2}{|c|}{ Kumeraftit kebele } & \multicolumn{2}{|c|}{ kokit-kebele } \\
\hline & Number & Percent & Number & Percent \\
\hline Pack animals & 21 & 16.67 & 7 & 5.00 \\
\hline Public transport vehicles & 10 & 7.93 & - & \\
\hline On foot & 82 & 65.00 & 143 & 95.00 \\
\hline Others & 13 & 10.3 & - & - \\
\hline
\end{tabular}

Source: Own Survey (2011).

\subsubsection{Income and Production Status and Resource Endowment}

For estimation of income volume of crop production and number of livestock owned are used as a proxy variable. Farm households who produce larger production together with large number of livestock ownership can have a possibility to visit the nearby small town frequently. And majority of the sample households in both sample sites forwarded that their purpose of visiting nearby small towns is market attendance. However, the volume of production and resource endowment varies considerably between the sites in the two kebeles; hence the purpose of market visit may vary accordingly. Land holding size and its fertility can be used as indicator of resource endowment.

The purpose of visit to small towns and the participation of non-farm activities are directly or indirectly related with the volume of production and resource endowment. Farm households in sample kebeles apart from selling their production, they also frequently visit small towns either to sell products obtained from non-farm activities or seeking non-farm jobs. Participation in non-farm activities also varies with income level, since poor farmers are expected to be widely practiced in low return non-farm activities and relatively rich farmers in high return ones.

\subsubsection{Distance from Small Towns}

Distance is approximated between farm homesteads and nearby small towns in terms of travel time. Distance is highly significant for farmers in the hinterlands of small towns. It could have a negative influence on the frequency of visit to nearby towns.

Farm households whose homesteads are closer to the nearby small town have more chance to visit the nearby small town more frequently than those farm households whose homesteads are located at a distant place. As presented in the preceding section of this chapter, frequency of visit to nearby small towns by farm households in from four times to daily indicate that majority of their homesteads are located relatively closer to the nearby small town (between 3 - $4 \mathrm{~km}$ ). On the other hand, in both sample kebeles some farm households who mentioned visiting the nearby small town once a month forwarded that their homesteads are located relatively within 7 - $9 \mathrm{~km}$ away from the nearby small towns. This indicated that, increased travel time to towns has negative ef- 
fect on households visit to towns.

Therefore, we can conclude that impact of distance on the pattern of frequency of visit to nearby small towns agrees with variation in the levels of infrastructures development and the nature of landscape between the two sample kebeles. The frequency of visit in turn has influence on rural-urban linkages between towns and their hinterlands.

\subsubsection{Infrastructure Development}

Infrastructure usually defines as underlying basic institutions and facilities or other essential elements that are necessary to sustain and enable economic growth. It represents a broad spectrum of activities and services without which no activity can undertake in the economy. It plays a key role in the society and constitutes the wheels, if not the engine of development. Infrastructure broadly classified in to physical, social and financial.

Improved infrastructure is a necessary condition for improving productivity in rural areas as well as for enhancing access of agricultural produce to both urban areas and export market. Therefore, in many ways developing countries, addressing rural-urban infrastructure gaps requires more government action. Infrastructure linkage to the economy is very multiple and complex, as it affects production and consumption directly, creates positive and negative spillover effects and involves large inflow of expenditure. It increases productivity; lowers production cost; improves quality of life; raises international competitiveness; attracts investment and helpful in urbanizing the economy.

In the study areas, infrastructure development is another local factor that may affects rural-urban linkages. There is some level of variation between the sample sites in the level of infrastructure development especially road transport. Rugged physical terrain, weak infrastructure based and inaccessibility are claimed to be some of the attributes of frequency of visit problems to nearby small towns.

\subsubsection{Availability of Financial Institutions}

The financial linkage of small towns to its hinterlands is based on the availability of financial institutions in the small towns, which will stimulate the rural people to use these institutions for loan and savings. In Metema town there are both governments and private formal financial institutions including branches of Amhara Credit and Saving Institutions.

The existence of financial institutions, especially banks in one area contribute a lot to positive rural-urban linkages and thereby play a significant role for livelihood diversification of rural households. Households who have access to credit can use it for a wide range of purposes such as for agriculture inputs purchase, for purchase of consumer durable and non-durable goods, for social services such as medical treatment and education.

In view of the fact that farmers in the study area have high access to formal credit service institutions, though some resort to informal credit sources, such as relatives and friends in urban areas.

There are thus very high financial flows from urban-based formal sources to rural households of the study kebeles. In the study sites, however, the main sources of financial capital for both rural and urban households may financial institutions.

The credit and saving scheme formed through the availability of financial institutions has helped to make rural-urban linkages sustainable and more effective towards initiating development activities. Credit and saving activities have cohesive effect between rural and urban areas and made rural-urban linkages stronger.

\subsubsection{Economic Dynamism of Towns}

The urban economies have potential for high growth if they can perform the role of producers of goods and services required by rural as well as urban economies and that of provider of markets and marketing services for rural outputs. Ample opportunities exist for strengthening and expanding the urban and rural economies for poverty alleviation. Thus strengthening local as well as regional level linkages to promote and expand economic activities is the major operational strategies of rural-urban linkage for promoting economic development and sharing its benefits to help the people escape wide spread poverty.

\subsubsection{Service Utilization Capacity}

The other indicators of linkage which are associated with service provision capacity of towns are the utilization of public services such as education and health. The utilization of these services is also a function of income. Measured in terms of aforementioned indicators households in both sample kebeles have relatively proportional 
income. And households in Metema woreda have a capacity to use education and health services both in the nearby and distant places. However the utilization of these services is also related to the level of education of households head, family size and income and attitude towards the returns of education.

\section{Conclusions and Recommendations}

\subsection{Conclusions}

Improved rural-urban linkage is a vehicle for balanced socio-economic development of both rural and urban areas. The following are the major conclusions that could be drawn from the patterns and forms of rural-urban linkages in the study areas.

The study results indicated that, volume of production and resource endowments do not vary considerably between the sites. Hence, the purposes of market visit do not vary accordingly. Larger proportion of farmers' households in both sample sites visits the nearby small town (Metema) once a week.

The numbers of business activities located in Metema are larger. This has influence on the service provision capacity of towns to the hinterland people. Service provision capacity has in turn impact on rural-urban linkage. The small towns and their corresponding hinterlands are located in the same geographical setting with proportional level of infrastructure development. The variation in the level of infrastructure has resulted in variation in rural-urban linkage. Hence, it implies that the availability of better infrastructure facilitates better rural-urban linkage.

\subsection{Recommendations}

Based on the observations made so far, the following are recommended to be in place to enhance rural-urban linkages and developmental role of the small towns in the study area.

Similar to other small towns in the country, the study site lack sufficient capacity to provide facilities and services to their dwellers and hinterland people. Hence, promoting the service provision capacity of small towns to provide sufficient services for its dwellers and hinterland people is necessary.

Road that connects rural and urban areas is very important to bring about all kinds of linkages. The low level of road network implies that the vast majority of areas is inaccessible to all weather roads reduces communication and mobility. It is important to prioritize road infrastructure development that links villages and local towns. This will enhance rural-urban linkages and facilitate mobility of people, flows of agricultural products and access to critical services.

It is important to facilitate the provision of credit/loan to farm households for input purchase from both formal financial institutions and credit and saving institutions. This will have an impact on the increment of production which in turn will have an impact on rural-urban linkage between towns and hinterlands.

Non-farm activities are underdeveloped. They can play a role in linking rural and urban areas. Therefore, promoting rural non-farm activities to create significant synergies between the rural and urban centers is needed to promote the role of small towns for surrounding rural areas development.

\section{References}

[1] Tacoli, C. (1998) Bridging the Divide Rural-Urban Interactions and Livelihoods Gatekeeper Series No 77, IIED United Kingdom.

[2] MoFED (2002) Development and Poverty Profile of Ethiopia Welfare Monitoring Unit, Addis Ababa.

[3] MoFED (2006) Ethiopia: PASDEP. Addis Ababa

[4] Demeke, E. (1998) Rural-Urban Linkages in East and North Shewa Zones. MA Thesis, Addis Ababa University, Addis Ababa.

[5] Yamane, Taro (1967) Statistics an Introductory Analysis. 2nd Edition, New York, Harper and Row.

[6] Fan S., et al. (2005) Rural and Urban Dynamics and Poverty. Evidence from China and India IFRI Washington.

[7] Douglass, M. (1998) A Regional Network Strategy for Reciprocal Rural-Urban Linkages. An Agenda for Policy Research with Reference to Indonesia Third World Planning Review, 23.

[8] Douglass, M. (1999) Rural-Urban Integration and Regional Economic Resilience: Strategies for the Rural-Urban Transition in North East Thailand, Bangkok, Thailand. 
[9] Eshetu Teklu (2007) Rural-Urban Linkage under Pastoral and Non-Pastoral Farming System: The Case of Fentale and Minjar-Shenkora Woreda. MA Thesis, Addis Ababa University, Addis Ababa.

[10] Ellis and Harris (2004) New Thinking about Urban and Rural Development. Guild Ford.

[11] Seraj, M. (2005) Livelihood Strategies and Their Implications Rural-Urban Linkages: The Case of Wolenkomi Town and Surrounding Rural Kebeles. MA Thesis, Addis Ababa University, Addis Ababa.

[12] Egziabher, T.G. (2005) Rural Urban Linkages in Ethiopia: The Need to Bridge the Divide. Proceeding of the 3rd International Policy Workshop in Regional and Local Development Studies, Addis Ababa, 21-33.

[13] UN/FIG (2004) Urban-Rural Interrelationship for Sustainable Development. Markech Declaration FIG Publication No. 33, Marrakech.

[14] UNDP (2000) Rural-Urban Linkages: An Emerging Policy Priority. Bureau of Development Policy, New York.

[15] Von Braun, J. (2007) Rural-Urban Linkages for Growth, Employment, and Poverty Reduction. International Conference on Ethiopian Economy, Addis Ababa, 7-9 June 2007, 1-21.

[16] Ellis, F. and Biggs, S. (2001) Evolving Themes in Rural Development 1950s-2000s. Overseas Development Institue, Oxford, Development Policy Review, 19, 437-448. http://dx.doi.org/10.1111/1467-7679.00143

[17] ILRI, International Livestock Research Institute (2005) Analysis of Cotton Marketing Chains: The Case of Metema Woreda, North Gondar Zone, Amhara National Regional State. MA Thesis, Haramaya University, Haramaya.

[18] CSA (2006) Statistical Abstract. Addis Ababa.

[19] CSA (2007) Statistical Abstract. Addis Ababa.

[20] WoARD, (Woreda Agriculture and Rural Development Office) (2009\&2011) Annual Report of Metema Woreda. Metema. 